\title{
Modelled impacts of extreme heat and drought on maize yield in South Africa
}

Robert Mangani ${ }^{\mathrm{A}}$, Eyob Tesfamariam ${ }^{\mathrm{B} *}$, Gianni Bellocchi ${ }^{\mathrm{C}}$, Abubeker Hassen ${ }^{\mathrm{D}}$

A, B Department of Plant and Soil Science,

University of Pretoria, Private Bag x20, Hatfield 0028, Pretoria, South Africa

${ }^{\mathrm{C}}$ Gianni Bellocchi

UREP, INRA 63000, Clermont-Ferrand, France

${ }^{D}$ Abubeker Hassen,

Department of Animal and Wildlife Sciences, Faculty of Natural- and Agricultural Sciences, University of Pretoria, Private Bag x20, Hatfield 0028, Pretoria 0002, South Africa

*Corresponding author

Email: eyob.tesfamariam@up.ac.za

Tel: $+27(0) 124204724$

\section{Abstract}

This study assessed two versions of the crop model CropSyst (i.e. EMS, existing; MMS, modified) for their ability to simulate maize (Zea mays L.) yield in South Africa. MMS algorithms explicitly account for the impact of extreme weather events (droughts, heat waves, cold shocks, frost) on leaf development and yield formation. The case study of this research was at an experimental station near Johannesburg where both versions of the model were calibrated and validated by using field data collected from 2004 to 2008 . The comparison of EMS and MMS showed considerable difference between the two model versions during extreme drought and heat events. MMS improved grain-yield prediction by $\sim 30 \%$ compared with EMS, demonstrating a better ability to capture the behaviour of stressed crops under a range of conditions. MMS also showed a greater variability in response when both versions were forced with scenarios of projected climate change, with increased severity of drought and increased temperature conditions at the horizons 2030 and 2050, which could drive decreased maize yield. Yield was even lower with MMS ( $8 v .11 \mathrm{t} \mathrm{ha}^{-1}$ for EMS) at the horizon 2050 , relative to the baseline scenario ( $\sim 13 \mathrm{t} \mathrm{ha}^{-1}$ at the horizon 2000). Modelling solutions 
accounting for the impact of extreme weather events can be seen as a promising tool for supporting agricultural management strategies and policy decisions in South Africa and globally.

Keywords: Extreme weather events, climate scenarios, crop modelling, maize

\section{Introduction}

Climate extremes such as droughts, heat waves, cold shocks and frost affect directly and indirectly cropping systems by altering physiology and behaviour of plants, with impacts on the productivity as well as the seasonality and quality of crop production (e.g. Motha 2011; Lesk et al. 2016). The weather-related risks faced by crops lie in the degree of exposure to different extremes, occurring with varying severity at different temporal and spatial scales and affecting various facets of crop growth and development, and farming practices (van der Velde et al. 2012). Extreme weather events adversely affect several physiological processes of plants, also causing important damages on crop yield. For example, drought and heat stresses triggered by low precipitation amounts and supra-optimal temperatures adversely affect crop transpiration and photosynthesis processes (Wolf et al. 1996; Porter and Semenov 2005). For maize in Africa, Lobell et al. (2011) reported a yield reduction by $1 \%$ associated with each degree day spent above $30{ }^{0} \mathrm{C}$ under optimal rain-fed conditions, which rises up to $1.7 \%$ under drought conditions experienced at around 21 days before anthesis. Yield variations due to an extreme event (cold temperature, high temperature or water deficit) are due to flower death and failure in pollination (high or low temperatures) (Hatfield et al. 2011) while water stress reduces seed set (Saini and Westgate 1999; Setter et al. 2001). All these effects are mediated by a change in Harvest Index (HI). 
Simulation modelling has an important role to play in understanding and quantifying the relationships, or trade-offs, between management and the production from cropping systems but mechanistic/dynamic simulation models mostly omit some potential large biophysical effects of extreme events (Nelson et al. 2014). The continuous rise in temperatures has prompted severe heat waves, drought, and other forms of extreme weather (Field et al. 2012). So, in order to prepare for potential future impacts, recent efforts have been made to understand how extreme weather events may change in future (Tebaldi 2007; Orlowsky and Seneviratne 2012) and impact on crop production (van der Velde et al. 2012; Chavez et al. 2015; Powell and Reinhard 2016). Global impact assessment studies have not been successful in addressing credibly the impact of extreme weather events on crop production (van der Velde et al. 2012; Zinyengere et al. 2014). This is because most crop models often fail to integrate the present day understanding of how crops respond to the impact brought by extreme weather events. Suggestions have been put forward that most of the existing crop models need an overhaul or an update in order for them to produce reliable results that can be used by policy developers for future planning (Rötter et al. 2011). In the case that existing models do not take into account explicitly the impacts of extreme weather events, there is a likelihood of overestimating yields if they are used in simulating future crop performances (Rötter et al. 2011). This has a negative impact on food and feed security planning at both local and global scales.

Considering that more than half of the maize production areas around the globe already experience heat stress and drought during the most sensitive moments of their growing cycle, special attention is placed in modelling the maize response to rising temperatures and drought (Lobell et al, 2013; Anderson et al, 2015; Carter et al, 2016). For instance, Lobell et al, (2013) used Agricultural Production Systems Simulators (APSIM) to show if the crop model can be able to reproduce the relationship between yields and extreme temperatures and with the 
seasonal rainfall in the Mid-Western United States. Knowledge of maize sensitivity to extreme temperature and drought is needed to understand sensitivity of food production to humancaused climate change and the potential for food production adaptation (Anderson et al, 2015). The focus of this study is on the cropping systems simulation model CropSyst, which provides a mechanistic view of the processes and multiple interactions occurring in cropping systems (Stöckle et al. 2003). Including a large set of management options, CropSyst can simulate a range of cropping systems in a variety of conditions. The model is used to represent environmental outputs and crop production (e.g. Bellocchi et al. 2002; Confalonieri et al. 2006; Sommer et al. 2008) and in impact studies (Tubiello et al. 2000; Abraha and Savage 2006; Tingem and Rivington 2009; Finger et al. 2011; Bocchiola et al. 2013; Eitzinger et al. 2013, Sommer et al. 2013). CropSyst is also being used for model comparison studies (Palosuo et al. 2011; Rötter et al. 2012), also as part of the AgMIP - The Agricultural Model Intercomparison and Improvement Project (Asseng et al. 2013; Bassu et al. 2014). Some model weaknesses have been highlighted (e.g. overestimation of crop yield) when simulating detailed multi-year datasets in a range of conditions (Todorovic et al. 2009).

In this study, we have assessed the performance of CropSyst to simulate maize crop growth and yield in South Africa under drought and excessive heat, using two versions of the model. The first one is the existing modelling solution (EMS) and the second is an improved CropSyst version referred to as the modified modelling solution (MMS). MMS consists of a component (coupled to EMS) that explicitly takes into consideration impacts of extreme weather events (high and low temperatures, and water deficit) on crop growth and development. Expressed mathematically, fundamental concepts were implemented into dedicated module (Villalobos et al. 2015) and coupled to CropSyst (EMS) to illustrate that the cropping system model has the elements needed to reproduce experimentally established system performances. Integrating a module implementing libraries for the impact of extreme events to a complex 
soil-vegetation-management model can thus provide useful insights into plant response. We thus extended CropSyst to include extreme impacts in a simplified way and used it to simulate multi-year datasets of crop growth and yield in South Africa. MMS emphasizes the effect of high and low temperatures and water deficit starting just before anthesis until maturity of the crop though other effects on the crop before and after anthesis were included which influences leaf area index and biomass accumulation (Bolanos and Edmeades 1996). This is particularly relevant for maize, which is particularly sensitive to extreme weather events occurring just before anthesis and during anthesis, usually resulting in drastic reduction of the potential yield. In this study, the effects of low temperatures will not be of significance due to the location of the study area (sub-tropical climate in sub-Saharan Africa), in which cold shocks and frost have not much of importance during the maize growing season.

The aim of this study was twofold: first to compare CropSyst outputs and experimental data, while assessing in a comparative fashion EMS and MMS, secondly to illustrate the sensitivity of both modelling solutions to alternative weather scenarios.

\section{Materials and methods}

\section{Model description}

CropSyst model is a generic multi-year crop model that works on a daily time step and accounts for the impact of agricultural management on crop production and the environment. Weather, soil and crop input data are used in estimating crop productivity under varied crop management practices (e.g. tillage operations) and water and nutrient conditions. For a detailed description of the model, the reader is referred to Donatelli et al. (1997) and Stöckle et al. (1994, 2003). The CropSyst release 3.02.23 is used in this study, adapted to, and embedded in the modelling platform BioMA (Biophysical Model Applications, release 0.4.2.0, http://bioma.jrc.ec.europa.eu). The CropSyst code has evolved since release 3, with 
release 4 being an update of previous versions of codes (http://modeling.bsyse.wsu.edu/rnelson/registration/cropsyst.htm). As this study started with the CropSyst solution developed in the BioMA framework (which is considered a valuable option for crop harvest forecasting in Europe by the European Commission Joint Research Centre, (https://ec.europa.eu/jrc/en), it continued with improving it with the equations consistent in the degree of complexity with generic crop simulators - developed in the frame of the EU-FP7 project MODEXTREME (http://modextreme.org). BioMA is a public domain software framework designed and implemented for developing, parameterizing and running modelling solutions based on biophysical models in the domains of agriculture and environment (http://www.biomamodelling.org). The application enables the running and comparing of alternative modelling solutions. The software is developed using Microsoft C\# language in the .NET framework. A customized CropSyst solution (MMS) was built by coupling algorithms explicitly considering the impacts of extreme weather events to the existing CropSyst version (EMS).

\section{Improved CropSyst Model (MMS)}

The hypothesis of the general framework was developed grounded on the fact that yield variations due to extreme events are effectuated by changes in the harvest index for water, heat and cold shocks whereas the main effects of weather on crop performance are already considered by existing crop models (Villalobos et al. 2015). The fact that extreme events effect of crop is dependent on the growth stage (van der Velde et al. 2012), is taken into account by using different thresholds for inducing the damage at different developmental stages. The different developmental stages were represented using a numerical code (DVS, unit less; 0; emergence; 1 anthesis; 2 maturity as proposed by van Keulen et al. (1982)). The impact of water stress $\left(F_{W}\right.$, unitless) around anthesis is calculated using Equation 1 (i.e., $0.9 \leq \mathrm{DVS} \leq$ $1.1)$. 
$F_{W}=\left\{\begin{array}{cl}\frac{F_{E}}{F_{\text {Ecrit }}} & F_{E \leq F_{\text {Ecrit }}} \\ 1 & \text { elsewhere }\end{array}\right.$

where $F_{E}$ denotes the fraction of transpiration that is not reduced (which is determined by the actual to potential transpiration and on the allowable soil water depletion); $F_{E c r i t}$ denotes the crop dependent parameter, set at 0.7 in this study.

In addition, the effect of extreme heat (function of maximum crop temperature) is overlapped, as follows:

$F_{H T}=\left\{\begin{array}{cc}1 & T_{C \max } \leq T_{\text {oheat }} \\ \frac{T_{C \text { max }-T_{100 h e a t}}}{T_{\text {oheat }-T_{100 \text { heat }}}} & T_{0 \text { heat }<} T_{C \max <}<T_{100 \text { heat }} \\ 0 & T_{C \max } \geq T_{100 \text { heat }}\end{array}\right.$

The strategy that was used in simulating the impact of heat shocks $\left(F_{H T}\right)$ (Equation 2) makes use of a linear response to maximum canopy temperature $\left(T_{C \max },{ }^{\circ} \mathrm{C}\right)$ driven by threshold $\left(T_{\text {oheat }},{ }^{\circ} \mathrm{C}\right)$ and critical $\left(T_{100 h e a t},{ }^{\circ} \mathrm{C}\right)$ temperatures during the reproductive phase of the crop (i.e., $0.9 \leq D V S \leq 2$ ).

Heat shocks $\left(F_{H T}\right)$ response function ranges between 0 and 1 (untiless) and modulates $H I$ in a different way if the extreme event occurs around the flowering stage (Equation 3) or from anthesis to maturity (Equation 4).

$$
\begin{aligned}
& H I_{A A}=\left[\left(\frac{1}{d_{A}} \sum_{1}^{d_{A}} F_{W}\right) \cdot\left(\prod_{1}^{d_{A}} F_{H T}\right)\right] \cdot H I_{\max } \\
& H I_{A A}=H I_{A A} \cdot\left[\left(1-F_{H T}\right) \cdot \frac{t}{d_{P A}}+F_{H T}\right]
\end{aligned}
$$

where $H I_{A A}, H I_{\max }$ and $H I$ (unitless) are the actual (after anthesis), potential and final harvest index at maturity, respectively; $t$ is time after anthesis; $d_{A}$ and $d_{P A}$ are the duration of the flowering and anthesis-maturity phases, respectively (which can be genotype-dependent). In 
this way, the effect of water stress on the $H I$ is averaged around flowering whereas that of heat stress is multiplicative, considering that high air temperatures can exacerbate the effect of the limited transpirational cooling under drought stress). Throughout the reproductive phase, each event of heat stress has an impact on the HI. In the absence of extreme weather events, MMS bypasses the extreme event module and acts as EMS.

\section{Site description}

This work is part of an on-going research, which started in 2004 at East Rand Water Care Works (ERWAT), Johannesburg, Gauteng, South Africa. The experimental site (26 01' 01' S, $28^{\circ} 16^{\prime} 55^{\prime \prime}$ E, $1577 \mathrm{~m}$ a.s.1.) has a clay loam soil, Hutton soil form (Soil Classification Working Group, 1991) or a loamy, kaolinitic, mesic, Typic Eutrustox. The soil has a pH $\left(\mathrm{H}_{2} \mathrm{O}\right)$ of 6 to 6.8 and an average soil profile depth $>1 \mathrm{~m}$. The study site experiences a single-peak of summer rainfall between October and April, averaging $680 \mathrm{~mm}$ during the cropping season. The occurrences of extreme weather events during the validation period (refer to Fig 1) were analysed using webXTREME which is an R-based web tool for calculating agro-climatic indices of extreme events (refer to http://modextreme.org/webxtreme/) (Klein et al. 2017). In webXTREME, the number of days with extreme aridity are measured as number of days in a growing season [Day of Year(DOY) start, DOYend] with ARID > ARIDcrit, where ARID (Agricultural Reference Index for Drought) denotes the aridity index proposed by Woli et al. (2012). In our study ARIDcrit was equivalent to 0.5. Heat shocks number of days in a growing season [DOYstart, DOYend] with daily maximum temperature (AIRTMAX) exceeding a user-defined threshold and in our study this value was $30^{\circ} \mathrm{C}$.

\section{Study design}

\section{Crop management and experimental layout}

Crop and soil data for model calibration and validation were collected during the period 20042008 on a medium season maize (Zea maize L.) hybrid (PAN6966). This work is part of an 
on-going research, which started in year 2004. Field plots of $25 \mathrm{~m}^{2}$ were arranged in a randomized complete block design comprising five fertilizer treatments and two cropping systems (dryland maize and irrigated maize-oat rotation). The crop was planted using a handdrawn planter in $0.9 \mathrm{~m}$ rows at rates of 80000 . Each plot consisted of 6 rows of $5 \mathrm{~m}$ in length, with one border on either side. Weeds were controlled manually, and plants were chemically protected against pests' diseases. Harvesting of plants was done manually using hands. The fertilizer treatments consisted of three sludge, one commercial inorganic fertilizer, and zero fertilizer treatments. For this study, the irrigated commercial inorganic fertilizer was used for model calibration and testing. The crop was fertilized according to crop $\mathrm{N}, \mathrm{P}$, and $\mathrm{K}$ requirements, with split applications at different growth stages as per the recommendations from Omnia Fertilizer Company (http://www.omnia.co.za). The total amount applied was 226 $\mathrm{kg} \mathrm{ha}^{-1} \mathrm{~N} ; 40 \mathrm{~kg} \mathrm{ha}^{-1} \mathrm{P}$; and $100 \mathrm{~kg} \mathrm{ha}^{-1} \mathrm{~K}$. This was applied in four splits. At planting $6 \mathrm{~kg}$ $\mathrm{ha}^{-1}(\mathrm{~N}) ; 9 \mathrm{~kg} \mathrm{ha}^{-1}(\mathrm{P}) ; 20 \mathrm{~kg} \mathrm{ha}^{-1}(\mathrm{~K})$; three weeks after planting $90 \mathrm{~kg} \mathrm{ha}^{-1}(\mathrm{~N}) ; 31 \mathrm{~kg} \mathrm{ha}^{-1}$ (P); no potassium; Five weeks after emergence $64 \mathrm{~kg} \mathrm{ha}^{-1}(\mathrm{~N})$ and $40 \mathrm{~kg} \mathrm{ha}^{-1}(\mathrm{~K})$; Seven weeks after emergence $66 \mathrm{~kg} \mathrm{ha}^{-1}(\mathrm{~N})$ and $40 \mathrm{~kg} \mathrm{ha}^{-1}(\mathrm{~K})$. The first split was spread uniformly and incorporated immediately into the soil top layer (0-0.2 m) with a manually operated, diesel powered rotovator (Agria), and the plots were levelled using rakes. The rest of the fertilizer was applied on the soil surface along plant rows.

\section{Crop sampling}

During the 2004/5 growing season, growth analysis and measurements of the aboveground biomass were performed at an interval of approximately two weeks. As for the remaining growing seasons, i.e. 2006/07-2008/09, plant sampling was carried out three times per year at different crop growth stages: at the eighth leaves, at soft dough and at physiological maturity. In 2004/05, grain yield was determined by harvesting maize crops from a 2 m length of the middle two rows. In the growing seasons 2006/07 and 2008/09, grain yield determination was 
performed from $2 \mathrm{~m}$ lengths of the middle four rows. The components (leaves, stems, and grain) were then dried in a forced-air oven at $60{ }^{\circ} \mathrm{C}$ to a constant mass to determine aboveground biomass, calculated as the sum of leaf, stem, and seed biomass.

\section{Soil sampling}

Soil samples were collected at the beginning of the study, before treatment application, using an auger from the following soil layers: $0-0.3 \mathrm{~m}, 0.3-0.6 \mathrm{~m}, 0.6-0.9 \mathrm{~m}$, and $0.9-1.2 \mathrm{~m}$. Additional soil samples were collected using a core sampler to determine bulk density and hydraulic properties of the soil, which were used to parameterize the model. At the end of each growing season, three soil samples were collected diagonally using auger from each plot (0-0.3 m, 0.3-0.6 m, 0.6-0.9 $\mathrm{m}$, and 0.9-1.2 m layers). The three samples from each layer per plot were combined and mixed to make a single homogenous soil sample per layer.

\section{Weather recording}

Weather data were collected from an automated weather station located at the study site. The automatic weather station consisted of an LI 200X pyranometer (LiCor, Lincoln, Nebraska, USA) for measuring solar radiation, an electronic relative humidity and temperature sensor installed in a Gill screen, an electronic cup anemometer (MET ONE, Inc. USA) to measure wind speed and electronic rain gauge (RIMCO, R/TBR tipping bucket rain gauge, Rauchfuss INSTRUMENTS division, Australia) and a CR10x data logger (Campbell Scientific Inc., USA). The sensors were placed $2 \mathrm{~m}$ above the ground. The weather data included daily values of maximum and minimum temperatures $\left({ }^{\circ} \mathrm{C}\right)$, rainfall $(\mathrm{mm})$, maximum and minimum relative humidities (\%), wind speed $\left(\mathrm{m} \mathrm{s}^{-1}\right)$ and global solar radiation $\left(\mathrm{MJ} \mathrm{m}^{-2} \mathrm{~d}^{-1}\right)$. Evapotranspiration was calculated using the Penman-Monteith model. 


\section{Calibration and validation}

Experimental data from the season $2004 / 05$ were used to calibrate model in Table 1 . The values of most parameters were set as measured experimentally (e.g. thermal time taken for each developmental stage), while others were extracted from the CropSyst user manual or other literature sources (e.g. the cut-off temperature above which the crop development stops). The data obtained during the seasons 2006/07, 2007/08 and 2008/09 were used for validating the model. The weather data for the seasons used during validation of the model are shown in Fig 1 . It can be noted that during the $2006 / 7$ season there was a combined effect of drought and heat as shown by a high number of occurrence of days with temperatures above 30 and the number of days with extreme aridity (ARID > 0.5) compared to the other two growing seasons (2007/08 and 2008/09). The two model versions were evaluated using the performance metrics (d, Index of agreement; MSE, Mean square error; EF, Modelling efficiency; R, Pearson's correlation coefficient) reported in Appendix 1.

\section{Simulations with climate scenarios}

\section{Climate data generation}

To run the CropSyst model (both EMS and MMS) under future projected climate change scenarios we made use of bias-corrected climate data (daily precipitation, minimum and maximum temperatures) generated from four General Circulation Models (GCM) - Regional Climate models (RCM) simulations namely: A) ECEARTH-RACMO B) HadGem-CCLM C) MPIESM-CCLM D) GFDLESM-RC (Table 2). Bias correction was performed using the statistical quantile mapping (Wilcke et al. 2013), independently for each variable. Some GCMs were making use of standard calendar (360-day calendar) whilst others were generating data using a 365-day (Gregorian) calendar. For crop modelling purposes standard days were adjusted by adding the missing days (five days per year or six days in the case of leap years) after bias correction was done to make the model output uniform. The added days contain the 
value of the previous day (e.g., July $30^{\text {th }}$ and July $31^{\text {st }}$ have the same value of precipitation, minimum and maximum temperatures). Other required variables for use as input to the simulation model, such as global solar radiation, relative humidity and wind speed, were derived based on methods by Duveiller et al. (2017).

Three-time horizons/time slices were used in the generation of climate data under four GCMRCM scenarios: current climate, 1991-2010; near future, 2021-2040; far future, 2041-2060. During the first 15 years of the current scenario (1991-2005), historical radiative forcing was used to drive the GCMs, whereas from 2006 and beyond they followed the Representative Concentration Pathway (RCP) 8.5 (Van Vuuren et al. 2011) due to the reason that RCP scenarios only start to differ from 2006 and onwards. RCP 8.5 is the most extreme of the emissions pathway scenarios developed for the IPCC's Fifth Assessment Report (Moss et al. 2010).

\section{Results and Discussion}

\section{Calibration and validation}

CropSyst was calibrated by adjusting the phenological and growth coefficients (Table 1) of the medium season maize hybrid PAN6966 through repeated iterations until the differences between observed and simulated yields were minimised as shown in Fig. 2. The same coefficients were used in subsequent validations. Figs. 3A and B show the performance of EMS and MMS in simulating grain yields and aboveground biomass, respectively. The performances of EMS and MMS were almost similar for grain yield simulation in 2007/08 and 2008/09, when the study site received adequate rain and very few counts of temperatures above the $30^{\circ} \mathrm{C}$. Both models slightly overestimated grain yield during the 2007/08 growing season. In contrast, the models slightly underestimated both maize grain yield and aboveground biomass during the 2008/09 growing season. The response of the two modelling 
solutions differed in the 2006/07 growing season, where the season was extremely arid and a high number of days with temperatures above $30^{\circ} \mathrm{C}$ prevailed. For this extremely rare dry and hot year, maize grain yield prediction by MMS (1 $\left.780 \mathrm{~kg} \mathrm{ha}^{-1}\right)$ was close to the measured value while the value predicted by EMS (2 $\left.603 \mathrm{~kg} \mathrm{ha}^{-1}\right)$ was roughly twice the observed value. Similar patterns were also observed with the aboveground biomass prediction, with MMS improving prediction capability by $34 \%$. Model performance indicators also show that MMS performed better than EMS (Table 3). The differences were also manifested in the harvest index (Fig 4). This agrees with a previous study by Todorovic et al. (2009), who reported the over-prediction of both aboveground biomass and grain yield by CropSyst and attributed this overestimation to the simplifications adopted by the model which limits it under severe water stress. This difference between EMS and MMS was also noted when predicting maize yield in near and far future horizons (next section). As can be seen in season 2006/7 the harvest index of MMS was reduced by approximately $12 \%$ in comparison to that of the EMS. Reduction in HI due to water and heat stress explains the fact that grain yield is much more affected than the total dry matter (Rafiee et al. 2010) and that has been taken into account into the MMS by the inclusion of new algorithms.

Comparison of grain yield average between EMS and MMS over different time horizons and under different scenarios.

Maize grain yield comparisons using existing and the modified CropSyst versions show some notable differences during different time periods (Fig. 5). As a general trend, observed with all the climate scenarios investigated, grain yields predicted at each time horizon with MMS were lower (of 14-30\%, Fig. 5) than with EMS. There has been a shift in the median yield at all-time horizons and under all climate scenarios (Fig. 6). A general trend of the median yield shifting was observed across all the four GCM's and three climate scenarios used. Using EMS, this shift goes from grain yield of $16000 \mathrm{~kg} \mathrm{ha}^{-1}$ in the 2000 horizon to approximately 11000 $\mathrm{kg} \mathrm{ha}^{-1}$ in the 2050 horizon. The MMS showed a range of a median shift from $11000 \mathrm{~kg} \mathrm{ha}^{-1}$ 
to $8000 \mathrm{~kg} \mathrm{ha}^{-1}$. The median yields at all-time horizons and under all climate scenarios were thus higher with EMS than with MMS. Contrasting results, depending on the climate scenario used, were observed in terms of percent variation of the simulated rain-fed maize yields for different time horizons using EMS and MMS with reference to 2000 time horizon yield (Table 4). With ECEARTH-RACMO and MPIESM-CCLM, simulated grain yields in 2020 and 2050 show some notable differences in comparison to the 2000 time horizon. For climate scenario HadGem-CCLM and GFDLESM-RCA, results on the extent to which the (Table 4) 2030 and 2050 time horizon grain yields deviated from the baseline (2000) were roughly the same between EMS and MMS. Climate scenario MPIESM-CCLM showed differences of approximately $16 \%$ and $13 \%$ between 2030 and 2050 respectively, while climate scenario HadGem-CCLM showed a difference of approximately 5\% at both 2030 and 2050 time horizons. At the time horizon of 2050, it can be shown that across all the climate scenarios used, there will be a decline ranging between $-14 \%$ and $-23 \%$ relative to the 2000 time horizon using the EMS whereas for the MMS decline in maize yield is between the range of $-3 \%$ and $-28 \%$. Decline in yields as we move away from the current scenario are well explained by the projected future climate. In the future, South Africa is expected to experience temperature increase and rainfall decline, which will translate into negative implications for maize crop production (Nhemachena 2009; Zinyengere et al. 2013). Fluctuations on the median coefficient of variation between time horizons were observed across all four scenarios but the general trend shows a high grain yield coefficient of variation when simulated by MMS in comparison to EMS (Fig. 7). This is an expected outcome, since EMS (which does not contain a specific module for the impact of extreme events) only simulates the effect of extreme events as normal stress events. Henceforth, this results in less crop yield variability over a period, in our case 20 years. In the case of MMS, the predicted crop yield showed more deviation from the average yield, thus increasing interannual variability. The rate of crop development 
commonly exhibits a linear response to temperature (Porter and Semenov, 2005). However, crop physiological processes related to growth such as photosynthesis and respiration display continuous and nonlinear responses to temperature (Gornall et al. 2010). The ability of a model to capture a wide range of possible non-linear crop responses produces outputs that deviate much from the average yields (Zinyengere et al. 2013). Consequently, model simulation outputs exhibiting increased yield variability are likely more realistic.

Comparison of aboveground biomass averages between EMS and MMS over different time horizons and under different scenarios.

The aboveground biomass simulated by EMS under future climate scenarios was higher in comparison to that simulated by MMS (Fig. 8), with no substantial differences among scenarios and time horizons. At each time horizon, the median value of simulated yield by the MMS was smaller than using EMS. In general terms, there was a shift in the median aboveground biomass towards lower values when moving from 2000 to 2050 time horizons (Fig. 9). The box plot displaying the coefficient of variation shows contrasting results depending on the climate scenarios. In particular, a higher aboveground biomass coefficient of variation was observed with MMS in comparison to EMS at each time horizon and over the climate scenarios used (Fig. 10). EMS and MMS did not show any difference with respect to simulated flowering and maturity dates (see Appendix 3 and 4 respectively). The simulated times to reach flowering and maturity were not affected by the modelling solution used but they reduced in the far future.

Research has shown that when crops are exposed to stress, such as a heat stress, they exhibit an escape mechanism (Sharp et al. 2009; Ivey and Carr, 2012). Such mechanisms stimulate a signal to cause an early transition of plant development from the vegetative to reproductive phase (Desclaux and Roumet, 1996). The triggering of such escape mechanisms increases the chances of forming seeds, which explains the reduction in the days needed to reach flowering 
and maturity. This allows the crop to escape from a potentially lethal stress (Riboni et al. 2014). Additionally, if a combination of drought and high temperature occurs around tasselling, it results in poor synchronization between silk emergence and pollen shedding. A reduction in the number of days needed to reach maturity also reduces the amount of dry matter accumulation, which results in reduced biomass and grain yield (Haverkort et al. 2013). This also explains the reductions in shift in the median grain and aboveground biomass towards the negative side as moving away from the current scenario to the far future time horizon (Fig. 6 and 9).

In summary, the incorporation of a module explicitly taking into account the impact of extreme weather events has improved the predictive capability of CropSyst. This was shown by lower grain yield and aboveground biomass from MMS simulations in comparison to EMS. This was also shown by a higher variability in the output from MMS in comparison to EMS. High variability in MMS output entails the ability of MMS to capture responses from a wide range of environments characterized by unavailability of water and presence of high temperatures. Simulations under different scenarios have shown that maize production in South Africa will be likely under threat due to climate change, which is likely associated with increased frequency and severity of extreme weather events. This was shown by changes in crop phenology and reductions in grain yield.

\section{Conclusions}

Overall, the modified CropSyst model implementing extreme event module improved maize simulations under extreme heat and drought conditions in South Africa and appears as a promising tool for supporting agricultural management strategies and policy decisions. Currently, information about impacts of extreme events is exceedingly needed by agricultural policymakers around the globe to plan for the coming decades where the frequency and 
intensity of extreme weather events are expected to increase. The general trend from the simulations made by EMS under future climate scenarios showed an overestimation of grain yield and aboveground biomass in comparison to MMS. The latter simulated more realistic values. This is especially relevant in policy making because discrepancies in simulation outputs (as those observed with EMS) can be critical when applying modelling tools to support food and feed security actions. In addition, the improved CropSyst version has demonstrated that extreme weather events under climate change (as emerging in terms of drought and heat) may add remarkable pressure on maize production. Our study did not include the negative effects that are brought about by the effects of extreme precipitation. Modelling efforts should also be directed towards improving existing models so that they can be able to capture and represent such effects in climate change impact assessment studies. If such damages are ignored they might also lead to underestimations of the impacts of climate change on rainfed

agriculture. We also recommend extending modelling works with the modified modelling solution of CropSyst to simulate various crops across all South African agro-ecological zones. In comparing these results with those of other studies, it must be taken into account that the experiments were conducted using one variety and this might vary when other varieties are used.

\section{Conflict of interest}

The authors declare no conflict of interest.

\section{Acknowledgements}

The research leading to these results has received funding from the European Community's Seventh Framework Programme (FP7/2007-2013) under grant agreement no. 613817 (MODEXTREME - Modelling vegetation response to EXTREMe Events, http://modextreme.org). The authors would like to express their appreciation of gratitude to 
Fabrizio Ginaldi and Gianni Fila of the Italian Council for Agricultural Research and Analysis of Agricultural Economics for their assistance in running the models.

\section{References}

Abraha MG, Savage MJ (2006) Potential Impacts of Climate Change on the Grain Yield of Maize for the Midlands of KwaZulu-Natal, South Africa. Agric Ecosyst Environ 115 (1). doi: $\underline{10.1016 / \text { j.agee.2005.12.020 }}$

Asseng S, Ewert F, Rosenzweig C, Jones JW, Hatfield JL, Ruane AC, Boote KJ, Thorburn PJ, Rötter RP, Cammarano D, Brisson N (2013) Uncertainty in simulating wheat yields under climate change. Nat. Clim. Change 3: 827-832. doi: 10.1038/nclimate1916

Anderson CJ, Babcock, BA, Peng Y, Gassman PW, Campbell TD (2015). Placing bounds on extreme temperature response of maize. Environ. Res. Lett, 10(12), 124001.

Bassu S, Brisson N, Durand JL, Boote K, Lizaso J, Jones JW, Rosenzweig C, Ruane AC, Adam M, Baron C, Basso B (2014) How do various maize crop models vary in their responses to climate change factors? Global Change Biol 20(7), 2301-2320. doi: $10.1111 / \mathrm{gcb} .12520$

Bellocchi G, Silvestri N, Mazzoncini M, Menini S (2002) Using the CropSyst model in continuous rainfed maize (Zea mays L.) under alternative management options. Ital J of Agron 6(1), 43-56

Bocchiola D, Nana E, Soncini A (2013) Impact of climate change scenarios on crop yield and water footprint of maize in the Po valley of Italy. Agricultural Water Management, 116, pp.50-61. doi: 10.1016/j.agwat.2012.10.009

Bolanos J, Edmeades GO (1996) The importance of the anthesis-silking interval in breeding for drought tolerance in tropical maize. Field Crops Res 48.1 (1996): 65-80. 
Bunting ES (1976) Accumulated Temperature and Maize Development in England. The J Agr Sci 87 (3): 577-583. doi: 10.1017/S0021859600033207

Carter EK, Melkonian J, Riha SJ, Shaw SB (2016) Separating heat stress from moisture stress: analyzing yield response to high temperature in irrigated maize. Environ. Res. Lett. 11(9), 094012.

Chavez E, Conway G, Ghil M, Sadler M (2015). An end-to-end assessment of extreme weather impacts on food security. Nature Climate Change. 5 (11):997-1001. doi: 10.1038/nclimate2747

Confalonieri R, Gusberti D, Bocchi S, Acutis M (2006) The CropSyst model to simulate the N balance of rice for alternative management. Agron Sustain Dev 26(4), 241. doi: 10.1051/agro:2006022

Desclaux, D, Roumet P (1996) Impact of Drought Stress on the Phenology of Two Soybean (Glycine Max L. Merr) Cultivars. Field Crops Res 46 (1): 61-70. doi: 10.1016/0378$\underline{4290(95) 00086-0}$

De Jager JM (1994) Accuracy of Vegetation Evaporation Ratio Formulae for Estimating Final Wheat Yield. Water SA-Pretoria- 20: 307-307. ISSN 0378-4738

Donatelli M, Stöckle C, Ceotto E, and Rinaldi M (1997) Evaluation of CropSyst for Cropping Systems at Two Locations of Northern and Southern Italy. Eur J Agron 6 (1): 35-45. doi: 10.1016/S1161-0301(96)02029-1

Duveiller G, Donatelli M, Fumagalli D, Zucchini A, Nelson R, Baruth B (2015) A dataset of future daily weather data for crop modelling over Europe derived from climate change scenarios. Theoretical and Applied Climatology, 1-13. doi:10.1007/s00704-015-16504

Eitzinger J, Thaler S, Schmid E, Strauss F, Ferrise R, Moriondo M, Bindi M, Palosuo T, Rötter R, Kersebaum KC, Olesen JE (2013) Sensitivities of Crop Models to Extreme Weather Conditions during Flowering Period Demonstrated for Maize and Winter 
Wheat in Austria. The J AGR SCI 151 (6): 813-835. doi: $\underline{10.1017 / S 0021859612000779}$

Field CB (2012) Managing the risks of extreme events and disasters to advance climate change adaptation: special report of the intergovernmental panel on climate change. Cambridge University Press. Cambridge and New York, p. 582

Finger R, Hediger W, Schmid S (2011) Irrigation as adaptation strategy to climate changea biophysical and economic appraisal for Swiss maize production. Climatic Change, 105(3-4), pp.509-528. doi:10.1007/s10584-010-9931-5

Haverkort AJ, Franke AC, Engelbrecht FA, Steyn JM (2013) Climate Change and Potato Production in Contrasting South African Agro-Ecosystems 1. Effects on Land and Water Use Efficiencies. Potato Res 56 (1): 31-50. doi:10.1007/s11540-013-9230-4

Hatfield JL, Boote KJ, Kimball BA, Ziska LH, Izaurralde RC, Ort D, Thomson AM, Wolfe D (2011). Climate impacts on agriculture: implications for crop production. Agron J 103, 2: 351-370. doi: 10.2134/agronj2010.0303

Ivey CT, Carr DE (2012) Tests for the joint evolution of mating system and drought escape in Mimulus. Ann Bot 2012; 109:583-98. doi: 10.1093/aob/mcr160

Jalota SK, Singh S, Chahal GB, Ray SS, Panigraghy S, Singh KB (2010) Soil Texture, Climate and Management Effects on Plant Growth, Grain Yield and Water Use by Rainfed Maize-wheat Cropping System: Field and Simulation Study. Agric Water Manage 97 (1): 83-90. doi: 10.1016/j.agwat.2009.08.012

Keeling PL, Greaves JA (1990) Effects of Temperature Stresses on Corn: Opportunities for Breeding and Biotechnology. In Proc. 45th Annual Corn and Sorghum Res. Conf., Chicago, 29-42

Kenny GJ, Harrison PA (1992) The Effects of Climate Variability and Change on Grape Suitability in Europe. J Wine Res 3 (3): 163-183. doi: 10.1080/09571269208717931 
Klein T, Samourkasidis A, Athanasiadis IN, Bellocchi G, Calanca P. (2017). webXTREME: R-based web tool for calculating agroclimatic indices of extreme events. Comput Electron Agric., 136, pp.111-116. doi: 10.1016/j.compag.2017.03.002

Lesk C, Rowhani P, Ramankutty N (2016) Influence of Extreme Weather Disasters on Global Crop Production. Nature 529 (7584): 84-87. doi:10.1038/nature16467

Lobell DB, Bänziger M, Magorokosho C, Vivek B (2011) Nonlinear Heat Effects on African Maize as Evidenced by Historical Yield Trials. Nat Clim Change 1 (1): 42-45. doi:10.1038/nclimate1043

Lobell DB, Hammer GL, McLean G, Messina C, Roberts MJ, Schlenker W (2013). The critical role of extreme heat for maize production in the United States. Nat Clim Change, 3(5), 497. doi: 10.1038/nclimate1832

McMaster GS, Wilhelm WW (1997) Growing Degree-Days: One Equation, Two Interpretations. Agr Forest Meteorol 87 (4): 291-300. doi: 10.1016/S0168$\underline{1923(97) 00027-0}$

Miranda JF, Cooley D, Sain SR, Tebaldi C (2016) A Comparison of US Precipitation Extremes under RCP8. 5 and RCP4. 5 with an Application of Pattern Scaling. Clim Change, 1-13. doi: 10.1007/s10584-016-1656-7

Monteith JL, Moss CJ (1977) Climate and the Efficiency of Crop Production in Britain [and Discussion]. Philos Trans R Soc Lond B Biol Sci 281 (980): 277-294. doi: 10.1098/rstb.1977.0140

Moss RH, Edmonds JA, Hibbard KA, Manning MR, Rose SK, Van Vuuren DP, Carter TR, Emori S, Kainuma M, Kram T, Meehl GA (2010) The next generation of scenarios for climate change research and assessment. Nature 463, 747-756. doi:10.1038/nature08823 
Motha, Raymond P (2011) The Impact of Extreme Weather Events on Agriculture in the United States. In Challenges and Opportunities in Agrometeorology, 397-407. Springer. http://link.springer.com/chapter/10.1007/978-3-642-19360-6_30

Nelson GC, Valin H, Sands RD, Havlík P, Ahammad H, Deryng D, Elliott J, Fujimori S, Hasegawa T, Heyhoe E, Kyle P (2014) Climate change effects on agriculture: Economic responses to biophysical shocks. Proceedings of the National Academy of Sciences of the United States of America 111, 3274-3279. doi: $10.1073 /$ pnas. 1222465110

Nhemachena C (2009) Agriculture and Future Climate Dynamics in Africa: Impacts and Adaptation Options. PhD Dissertation in Environmental Economics, University of Pretoria, South Africa

Orlowsky B, Seneviratne SI (2012) Global Changes in Extreme Events: Regional and Seasonal Dimension. Climatic Change 110 (3-4): 669-696. doi:10.1007/s10584-011$0122-9$

Palosuo T, Kersebaum KC, Angulo C, Hlavinka P, Moriondo M, Olesen JE, Patil RH, Ruget F, Rumbaur C, Takáč J, Trnka M (2011) Simulation of winter wheat yield and its variability in different climates of Europe: a comparison of eight crop growth models. Eur J Agron 35 (3): 103-114. doi: 10.1016/j.eja.2011.05.001

Porter JR, Semenov AM (2005) Crop Responses to Climatic Variation. Philos Trans R Soc Lond B Biol Sci 360 (1463): 2021-2035. doi: 10.1098/rstb.2005.1752

Powell JP, Reinhard S (2016). Measuring the effects of extreme weather events on yields. Weather and Climate Extremes. 12:69-79. doi: 10.1016/j.wace.2016.02.003 Rafiee M, Shakarami G. (2010) Water Use Efficiency of Corn as Affected by Every Other Furrow Irrigation and Planting Density. World Appl Sci J. 11 (7):826-829. 
Rötter RP, Carter TR, Olesen JE, Porter JR (2011) Crop-climate Models Need an Overhaul. Nat Clim Change 1: 175-177

Saini HS, Westgate ME (1999) Reproductive development in grain crops during drought. In Advances in agronomy (Vol. 68, pp. 59-96). Academic Press.

Setter TL, Flannigan BA, Melkonian J (2001) Loss of kernel set due to water deficit and shade in maize. Crop Sci. 5: 1530-1540. doi:10.2135/cropsci2001.4151530x

Sharp RG, Else MA, Cameron RW, Davies WJ (2009) Water deficits promote f lowering in Rhododendron via regulation of pre and post initiation development. Sci Hortic (Amsterdam) 120:511-7. doi: 10.1016/j.scienta.2008.12.008

Shaw RH (1983) Estimates of Yield Reductions in Corn Caused by Water and Temperature Stress. Crop Reaction to Water and Temperature Stress in Humid, Temperate Climates. Westview Press Inc., New York, 49-65

Sommer R, Kienzler K, Conrad C, Ibragimov N, Lamers J, Martius C, Vlek P (2008) Evaluation of the CropSyst Model for Simulating the Potential Yield of Cotton. Agron Sustain Dev 28 (2): 345-354. doi:10.1051/agro:2008008

Sommer R, Glazirina M, Yuldashev T, Otarov A, Ibraeva M, Martynova L, Bekenov M, Kholov B, Ibragimov N, Kobilov R, Karaev S, Sultonov M, Khasanova F, Esanbekov M, Mavlyanov D, Isaev S, Abdurahimov S, Ikramov R, Shezdyukova L, de Pauw E, (2013) Impact of climate change on wheat productivity in Central Asia. Agric. Ecosyst. Environ. 178, 78e99. doi: 10.1016/j.agee.2013.06.011

Stöckle CO, Donatelli M, Nelson R (2003) CropSyst, a Cropping Systems Simulation Model. Eur J Agron 18 (3): 289-307. doi: 10.1016/j.agee.2013.06.011

Stöckle CO, Martin MA, Campbell GS (1994) CropSyst, a Cropping Systems Simulation Model: Water/Nitrogen Budgets and Crop Yield. Agric Sys 46 (3): 335-359. doi: $\underline{10.1016 / 0308-521 X(94) 90006-2}$ 
Stockle CO, Cabelguenne M, Debaeke P (1997) Comparison of CropSyst performance for water management in southwestern France using sub models of different levels of complexity. European Journal of Agronomy 7 (1): 89-98. doi: 10.1016/S1161$\underline{0301(97) 00033-6}$

Tanner CB, Sinclair TR (1983) Efficient water use in crop production: Research or ReSearch? In:Taylor HM, Jordan WR, Sinclair TR. (Eds.), Limitations to Efficient Water Use in Crop Production, Chapter 1A. Agron J, pp. 1-27

Tebaldi, Claudia others (2007) Going to the Extremes: An Intercomparison of ModelSimulated Historical and Future Changes in Extreme Events. Climatic Change 79: 198. doi: 10.1007/s10584-006-9051-4Tingem M, Rivington M (2009) Adaptation for crop agriculture to climate change in Cameroon: turning on the heat. Mitigation and Adaptation Strategies for Global Change, 14(2), pp.153-168. doi:10.1007/s11027008-9156-3

Todorovic, M, Albrizio R, Zivotic L, Saab MTA, Stöckle C, Steduto P (2009) Assessment of AquaCrop, CropSyst, and WOFOST Models in the Simulation of Sunflower Growth under Different Water Regimes. Agron J 101 (3): 509-521. doi:10.2134/agronj2008.0166s

Tubiello FN, Donatelli M, Rosenzweig C, Stockle CO (2000) Effects of Climate Change and Elevated $\mathrm{CO}_{2}$ on Cropping Systems: Model Predictions at Two Italian Locations. Eur J Agron 13 (2): 179-189. doi: 10.1016/S1161-0301(00)00073-3

van der Velde, M, Tubiello FN, Vrieling A, Bouraoui F (2012) Impacts of Extreme Weather on Wheat and Maize in France: Evaluating Regional Crop Simulations against Observed Data. Clim Change 113 (3-4): 751-765. doi:10.1007/s10584-011-0368-2 Van Keulen H, Penning De Vries FWT, Drees EM (1982) A summary model for crop growth. In Simulation of plant growth and crop production. Pudoc. pp. 87-97, 
Van Vuuren DP, Edmonds J, Kainuma M, Riahi K, Thomson A, Hibbard K, Hurtt GC, Kram T, Krey V, Lamarque JF, Masui T (2011) The Representative Concentration Pathways: An Overview. Clim Change 109: 5-31. doi:10.1007/s10584-011-0148-z

Villalobos F, Tardieu F, Bellocchi G, de Melo e Abreu JP, Parent B, Morales A, Zaka S, Louarn G, Borras D, Martin R, Leolini L, Moriondo M, Donatelli M, Confalonieri R, Bindi M, Testi L (2015) Report on modelling approaches for simulating the impact of extreme events on agricultural production. EU-FP7 MODEXTREME (http://modextreme.org), Deliverable number: D1.2 Accessed online http://prodinra.inra.fr/ft?id=\{A6CBE276-3AA4-47D6-B4B0-B6F4D1FBBD80\} on 20/02/2016.

Wilcke RAI, Mendlik T, Gobiet A (2013) Multi-Variable Error Correction of Regional Climate Models. Clim Change 120 (4): 871-887. doi:10.1007/s10584-013-0845-x

Wolf J, Evans LG, Semenov MA, Eckersten H, Iglesias A (1996) Comparison of Wheat Simulation Models under Climate Change. I. Model Calibration and Sensitivity Analyses. Clim Research 7 (3): 253-270.

Woli P, Jones, JW, Ingram KT, Fraisse CW (2012). Agricultural Reference Index for Drought (ARID) Agron. J., 104 (2012), pp. 287-300. doi: 10.2134/agronj2011.0286.

Zinyengere N, Crespo O, Hachigonta S (2013) Crop Response to Climate Change in Southern Africa: A Comprehensive Review. Glob Planet Change 111: 118-126. doi: 10.1016/j.gloplacha.2013.08.010

Zinyengere N, Crespo O, Hachigonta S, Tadross M (2014) Local Impacts of Climate Change and Agronomic Practices on Dry Land Crops in Southern Africa. Agric Ecosyst Environ 197: 1-10. doi: 10.1016/j.agee.2014.07.002 


\section{Tables}

Table 1 Units, values and sources of parameters that were used in calibrating the CropSyst models

\begin{tabular}{|c|c|c|c|}
\hline Parameter & Unit & Value & Source \\
\hline Boolean value for $\mathrm{C} 3$ crops $(1=\mathrm{C} 3,0=\mathrm{C} 4)$ & - & 0 & Manual \\
\hline $\begin{array}{llll}\text { Development Susceptibility } & \text { To Water } \\
\text { Stress } & & & \end{array}$ & unitless & 1 & Manual \\
\hline Thermal Time To Emergence & ${ }^{\circ} \mathrm{C} \mathrm{day}^{-1}$ & 85 & Measured \\
\hline Thermal Time To Flowering & ${ }^{\circ} \mathrm{C}_{\text {day }}{ }^{-1}$ & 1000 & Measured \\
\hline Thermal Time To Begin Yield Formation & ${ }^{\circ} \mathrm{C}$ day $^{-1}$ & 1200 & Measured \\
\hline Thermal Time To Maturity & ${ }^{\circ} \mathrm{C} \mathrm{day}^{-1}$ & 1700 & Measured \\
\hline Base Temperature for Development & ${ }^{\circ} \mathrm{C}$ & 10 & $\begin{array}{c}\text { Bunting (1976), Shaw } \\
\text { (1983), Keeling and } \\
\text { Greaves (1990) }\end{array}$ \\
\hline Cut-off Temperature for Development & ${ }^{\circ} \mathrm{C}$ & 30 & Hensley et al. (1994) \\
\hline Initial Leaf Area Index & $\mathrm{m}^{2} \mathrm{~m}^{-2}$ & 0.03 & Measured value \\
\hline Minimum Initial Green Leaf Area Index & $\mathrm{m}^{2} \mathrm{~m}^{-2}$ & 0.05 & Measured value \\
\hline Leaf Area Index Initial Value Shape & unitless & 1.5 & Measured value \\
\hline Development Stage Critical & unitless & 3 & Default value \\
\hline Regrowth Development Stage Critical & unitless & 1.5 & Default value \\
\hline Maximum Radiation Use Efficiency & $\mathrm{g} \mathrm{MJ}^{-1}$ & 3.7 & Measured \\
\hline Base Temperature For Growth & ${ }^{\circ} \mathrm{C}$ & 10 & Hensley et al. (1994) \\
\hline Optimum Temperature For Growth & ${ }^{\circ} \mathrm{C}$ & 25 & $\begin{array}{c}\text { Kenny and Harrison } \\
\text { (1992), McMaster and } \\
\text { Wilhelm (1997) }\end{array}$ \\
\hline Extinction Coefficient Solar Radiation & unitless & 0.57 & Default \\
\hline Full Canopy Water Uptake Maximum & $\mathrm{kg} \mathrm{m}^{-2} \mathrm{~d}^{-1}$ & 10 & Default \\
\hline $\begin{array}{l}\text { Thermal Time To End Green Leaf Area } \\
\text { Index }\end{array}$ & ${ }^{\circ} \mathrm{C}$ day $^{-1}$ & 1600 & Measured \\
\hline Full Canopy Coefficient & unitless & 1 & Measured \\
\hline Specific Leaf Area & $\mathrm{m}^{2} \mathrm{~kg}^{-1}$ & 15 & Measured \\
\hline Stem Leaf Partition & unitless & 4 & Measured \\
\hline Biomass-transpiration coefficient & $(\mathrm{Pa})^{\mathrm{a}}$ & 7 & Stöckle et al. (1997) \\
\hline Height Maximum & $\mathrm{m}$ & 3.20 & Measured \\
\hline LAI Maximum & $\mathrm{m}^{2} \mathrm{~m}^{-2}$ & 6 & Measured \\
\hline Maximum Rooting Depth & $\mathrm{m}$ & 1.6 & Measured \\
\hline Harvest Index & unitless & 0.47 & Measured \\
\hline Leaf Duration & ${ }^{\circ} \mathrm{C}$ day $^{-1}$ & 1350 & Measured \\
\hline
\end{tabular}


Table 2 Selected GCM-RCM simulations (horizontal resolution of $\sim 50 \mathrm{~km}$ ) used for the study

\begin{tabular}{lll}
\hline Symbol & Selected GCM-RCM simulation & Short name \\
\hline A & ICHEC-EC-EARTH_KNMI-RACMO22T & ECEARTH-RACMO \\
B & MOHC-HadGEM2-ES_CLMcom-CCLM4-8-17 & HadGem-CCLM \\
C & MPI-M-MPI-ESM-LR_CLMcom-CCLM4-8-17 & MPIESM-CCLM \\
D & NOAA-GFDL-GFDL-ESM2M_SMHI-RCA4 & GFDLESM-RCA \\
\hline
\end{tabular}

Table 3 Performance measures of the existing and modified CropSyst versions for maize aboveground biomass and grain yield using combined data collected during the 2006/07 to 2008/09 growing seasons

\begin{tabular}{lccccc}
\hline Variable & Model & d & RMSE & EF & $\mathbf{r}^{2}$ \\
\hline Aboveground biomass & EMS & 0.84 & 1.25 & 0.86 & 0.93 \\
& MMS & 0.94 & 0.85 & 0.95 & 0.97 \\
Grain yield & EMS & 0.86 & 3.63 & 0.89 & 0.94 \\
& MMS & 0.96 & 1.79 & 0.94 & 0.97 \\
\hline
\end{tabular}

Table 4 Variation percentage of the simulated rain fed maize grain yields under different climate scenarios with $\mathrm{A}=\mathrm{ECEARTH}-\mathrm{RACMO}, \mathrm{B}=\mathrm{HadGem}-\mathrm{CCLM}, \mathrm{C}=\mathrm{MPIESM}-\mathrm{CCLM}$ and $\mathrm{D}=$ GFDLESM-RCA at different time horizons using the existing CropSyst modelling solution (EMS) and modified CropSyst modelling solutions (MMS) with reference to 2000 time horizon yield

\begin{tabular}{|l|c|c|c|c|}
\hline & \multicolumn{1}{|c|}{ EMS } & \multicolumn{1}{c|}{ MMS } & EMS & MMS \\
\hline GCM Name & \multicolumn{2}{|c|}{$\mathbf{2 0 3 0}$} & \multicolumn{2}{c|}{$\mathbf{2 0 5 0}$} \\
\hline ECEARTH-RACMO & -26.18 & -21.03 & -28.8 & -23.8 \\
\hline HadGem-CCLM & -15.91 & -14.59 & -20.32 & -20.88 \\
\hline MPIESM-CCLM & -5.11 & -20.96 & -14.23 & -27.56 \\
\hline GFDLESM-RCA & -3.73 & -3.91 & -10.71 & -14.07 \\
\hline
\end{tabular}




\section{Figures}

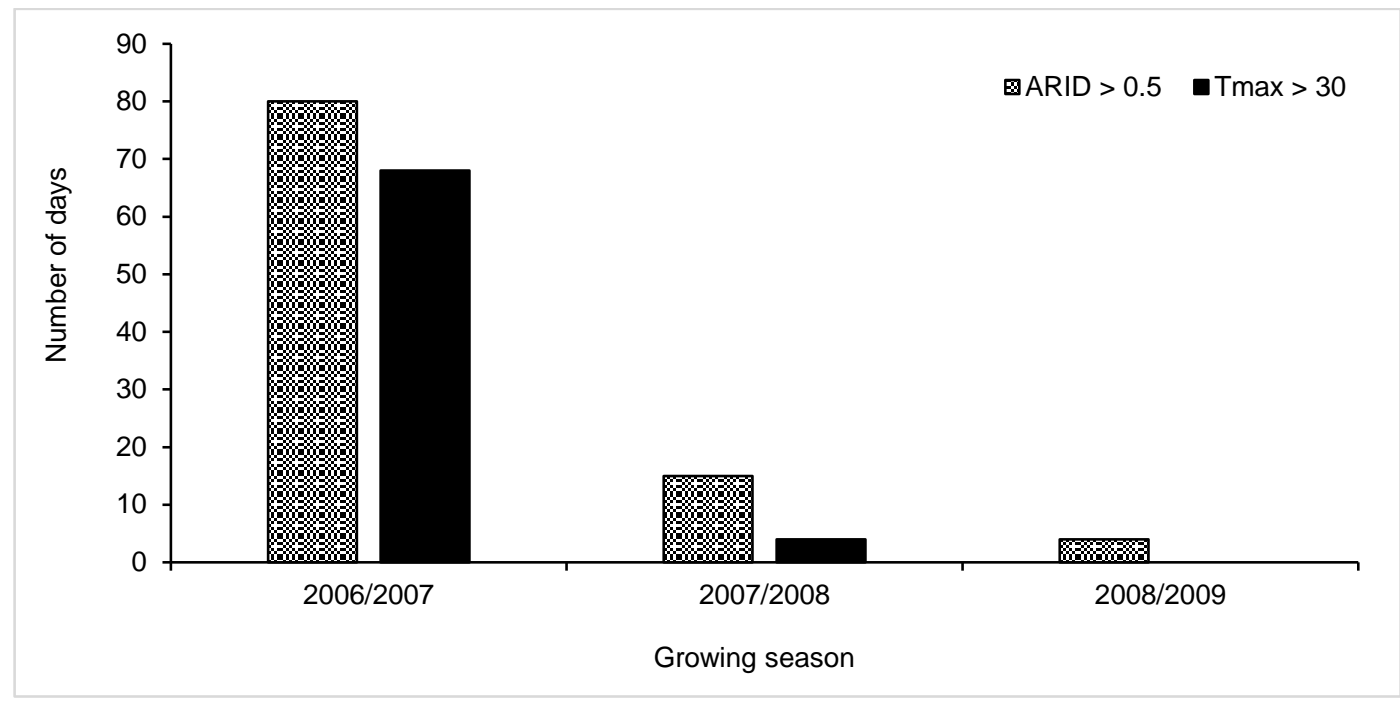

Fig. 1 Analysis of the occurrence of extreme heat (number of days with maximum temperature $(\operatorname{Tmax})>30^{\circ} \mathrm{C}$ ) and extreme aridity (number of days with ARID $\geq 0.5$ ) during November and April at East Rand Water Care Works (ERWAT), Johannesburg, Gauteng, South Africa (26 01' 01' S, 28 16' 55” E, 1577 m.a.s.1.), from growing seasons 2006/2007 to 2008/2009

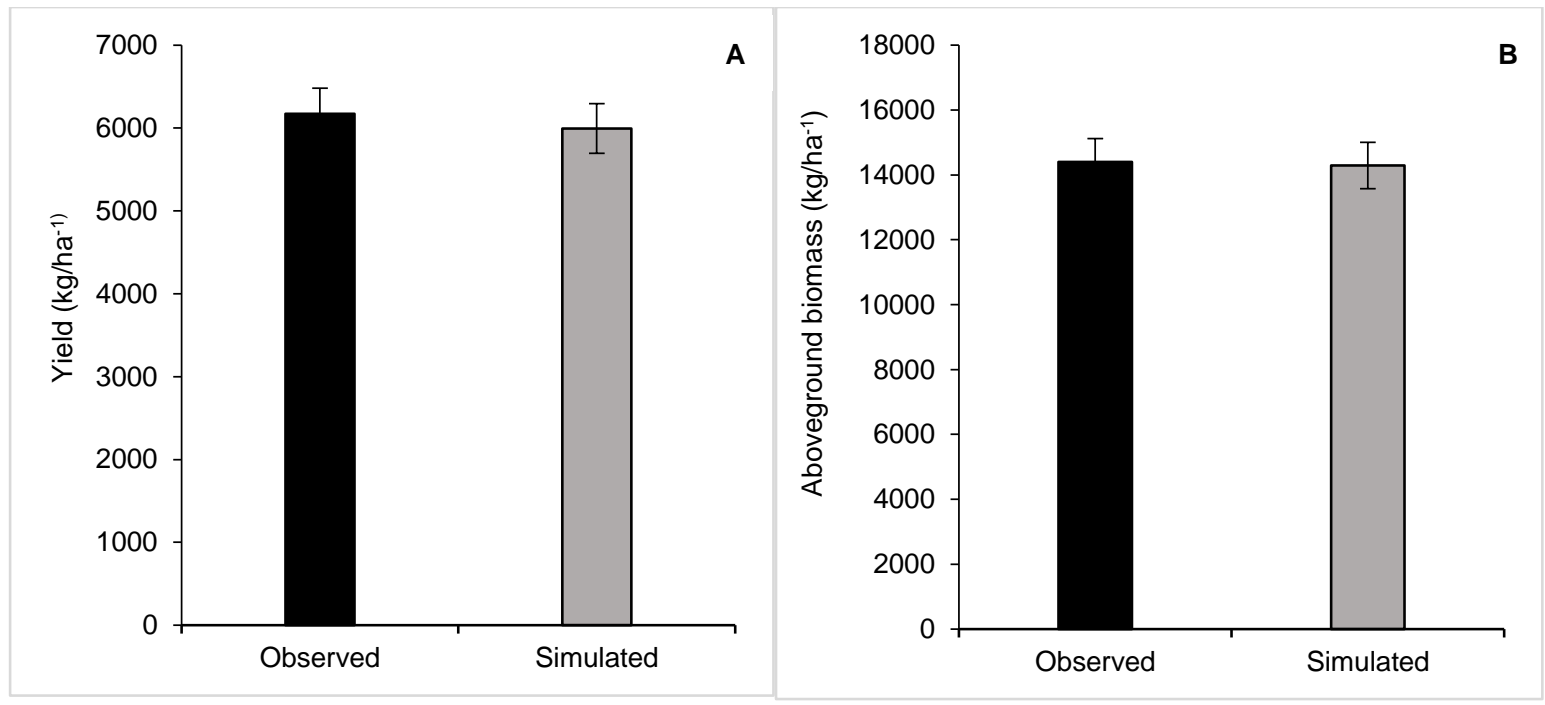

Fig. 2 Calibration simulations for A) grain yield and B) aboveground biomass of maize crop (by adjusting varietal phenology and growth coefficients) using existing modelling solution for 2004/05 season. 

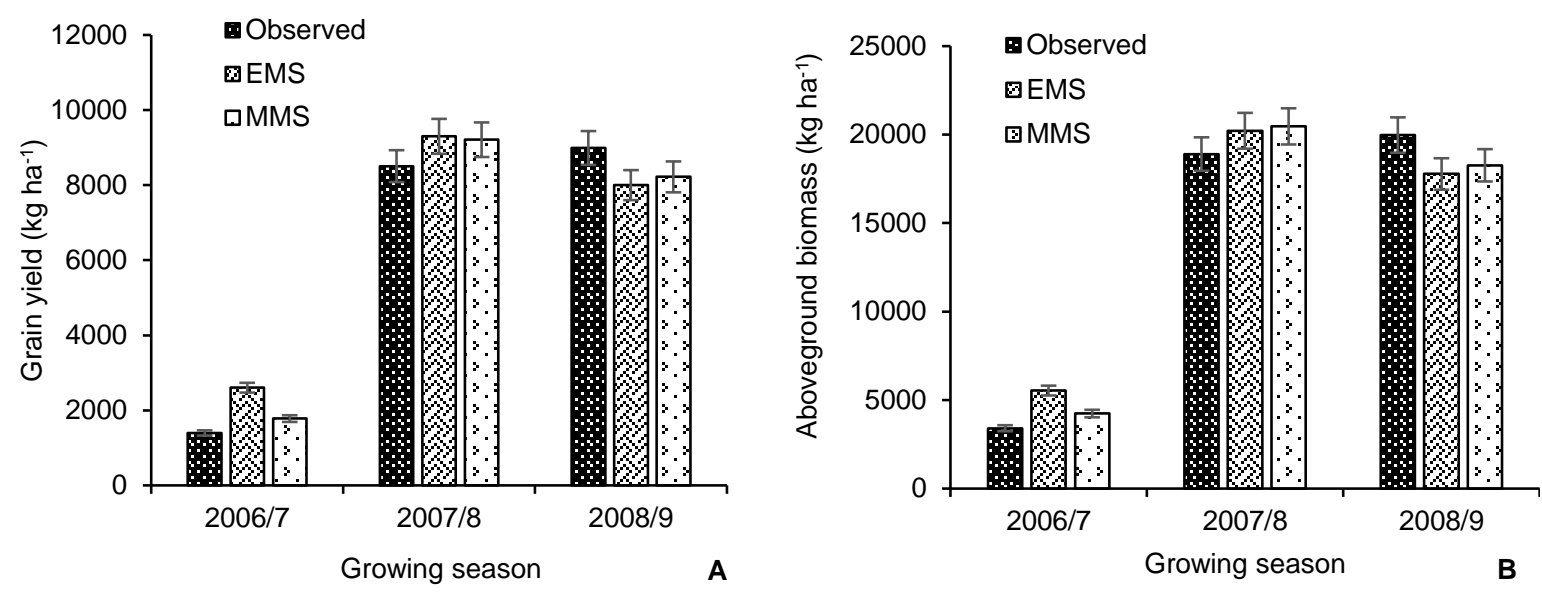

Fig. 3 Model corroboration (validation) of existing modelling solution and modified modelling solution for A) maize grain yield and B) aboveground biomass

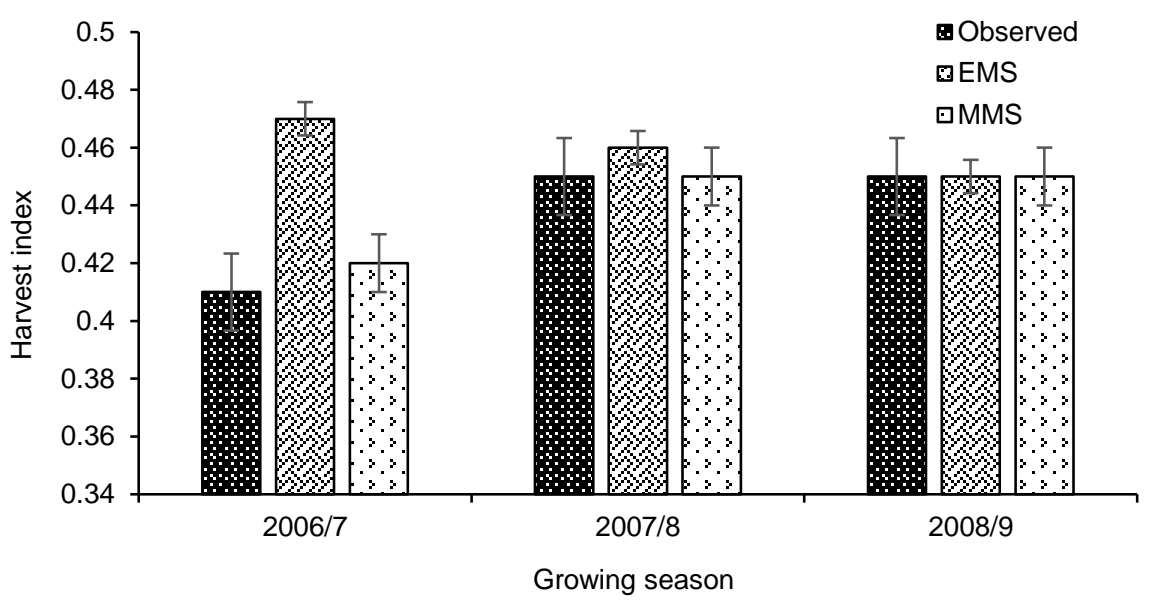

Fig. 4 Harvest index during corroboration (validation) of existing modelling solution and modified modelling solution for maize grain yield

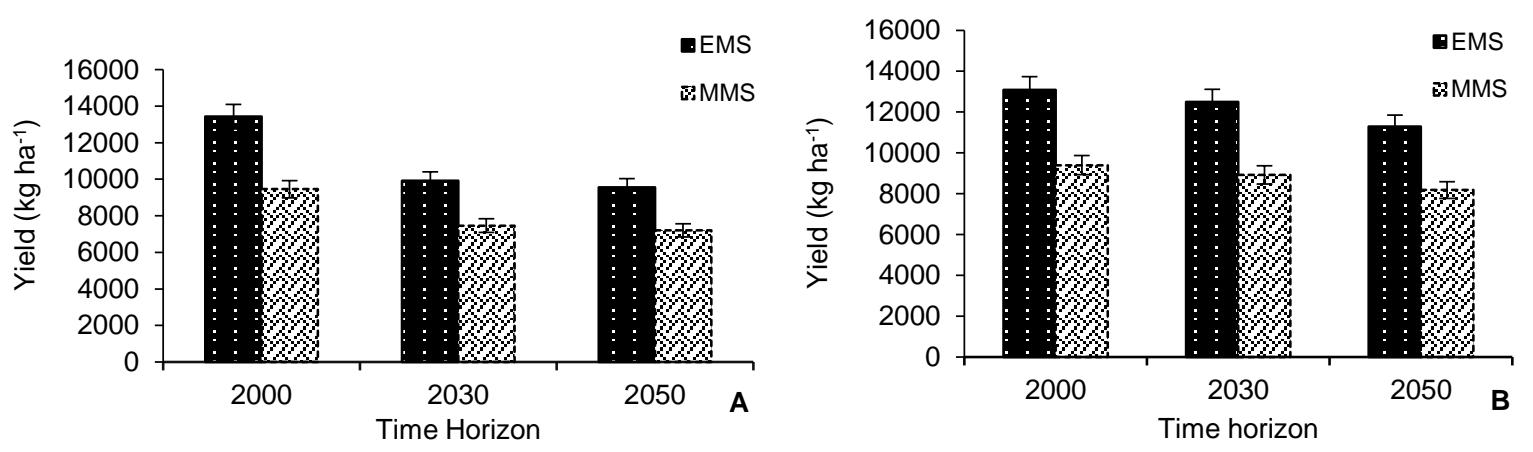



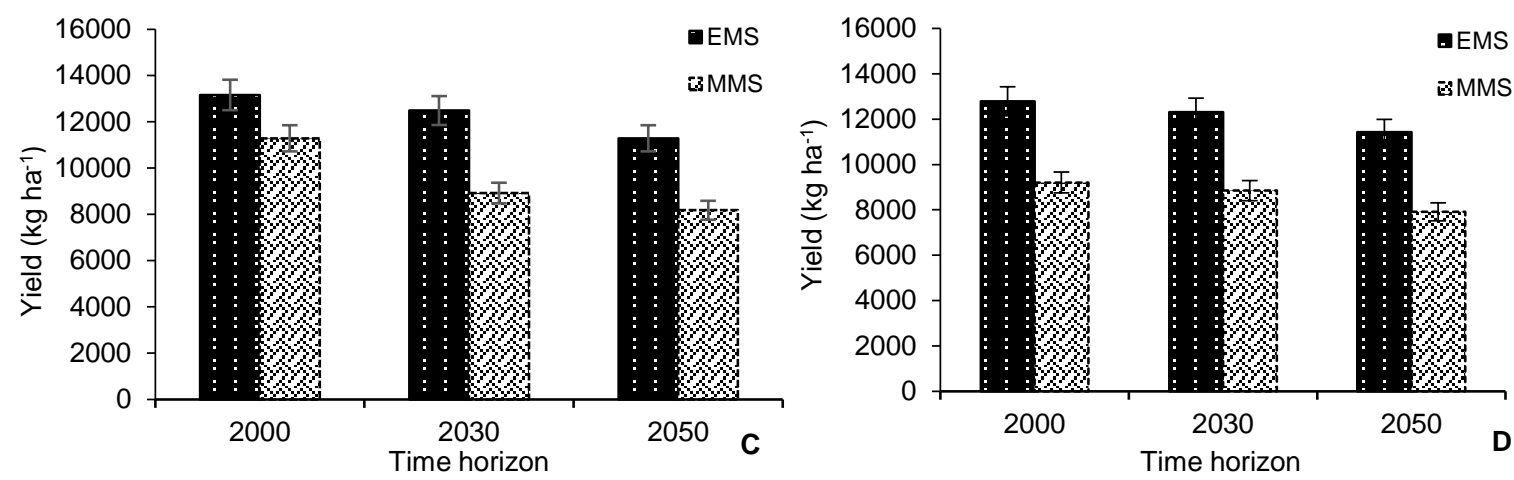

Fig. 5 Comparison of simulated rain fed maize yields under different climate scenarios with $\mathrm{A}=\mathrm{ECEARTH}-\mathrm{RACMO}, \mathrm{B}=\mathrm{HadGem}-\mathrm{CCLM}, \mathrm{C}=\mathrm{MPIESM}-\mathrm{CCLM}$ and $\mathrm{D}=$ GFDLESM-RCA using the existing (EMS) and modified (MMS) CropSyst modelling solutions for different time horizons
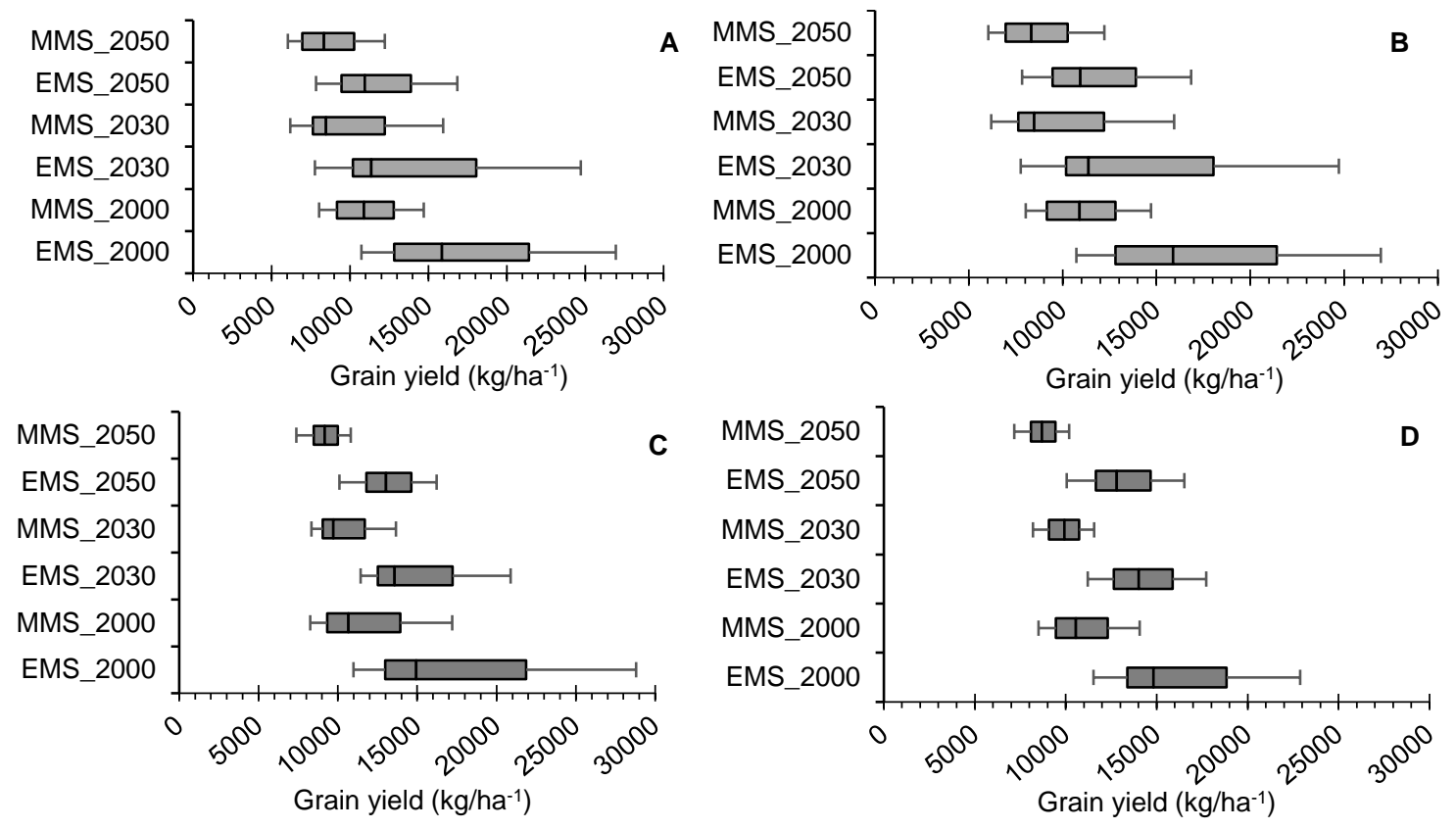

Fig. 6 Grain yield box plots of simulated rain fed maize yields under different climate scenarios with $\mathrm{A}=\mathrm{ECEARTH}-\mathrm{RACMO}, \mathrm{B}=\mathrm{HadGem-CCLM}, \mathrm{C}=\mathrm{MPIESM}-\mathrm{CCLM}$ and $\mathrm{D}=$ GFDLESM-RCA using the existing (EMS) and modified (MMS) CropSyst modelling solution for different time horizons 


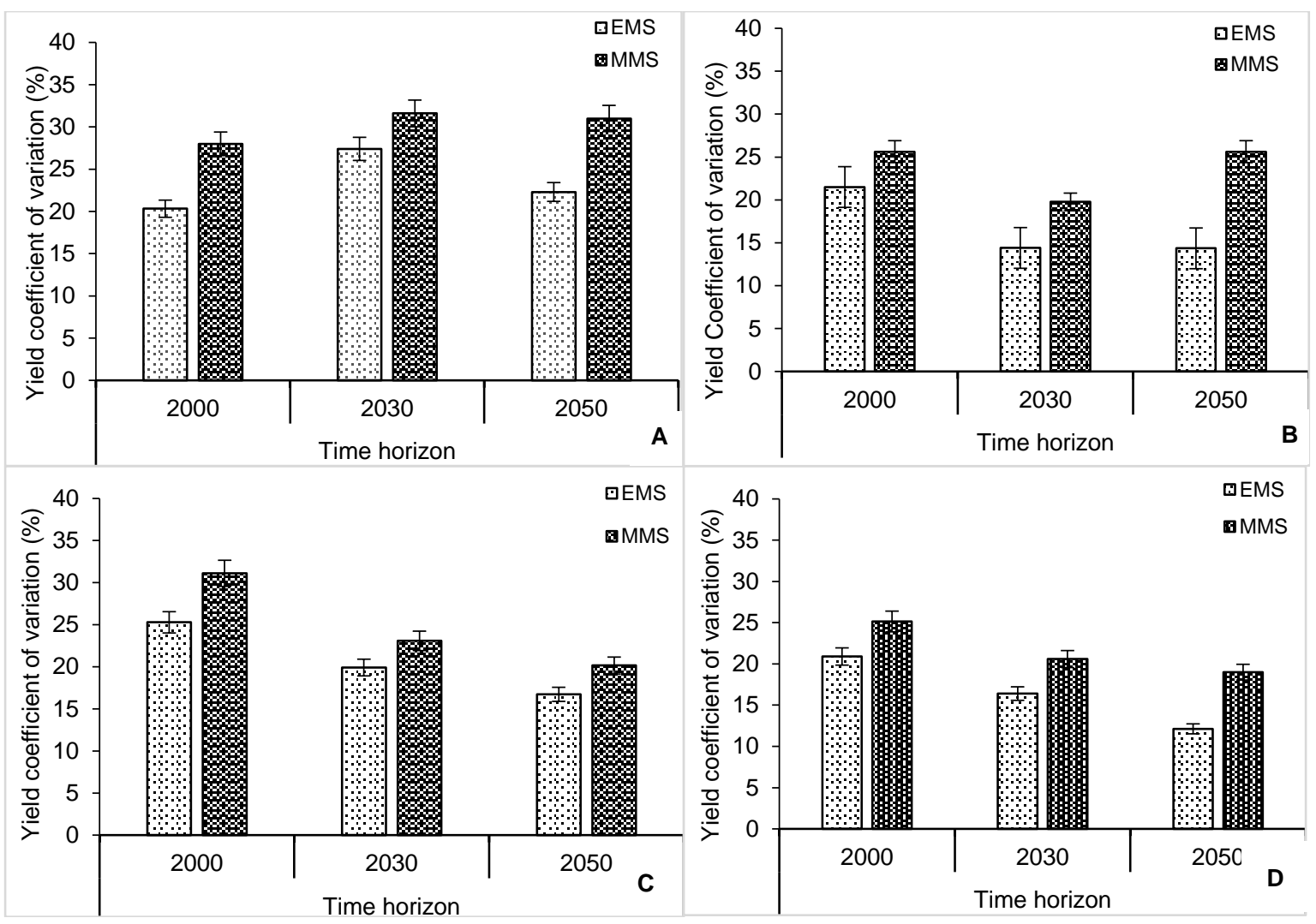

Fig. 7 Comparisons of the coefficient of variation of simulated rain fed maize grain yields under different climate scenarios with $\mathrm{A}=\mathrm{ECEARTH}-\mathrm{RACMO}, \mathrm{B}=\mathrm{HadGem}-\mathrm{CCLM}$, $\mathrm{C}=$ MPIESM-CCLM and D=GFDLESM-RCA using the existing (EMS) and modified (MMS) CropSyst modelling solutions for different time horizons 

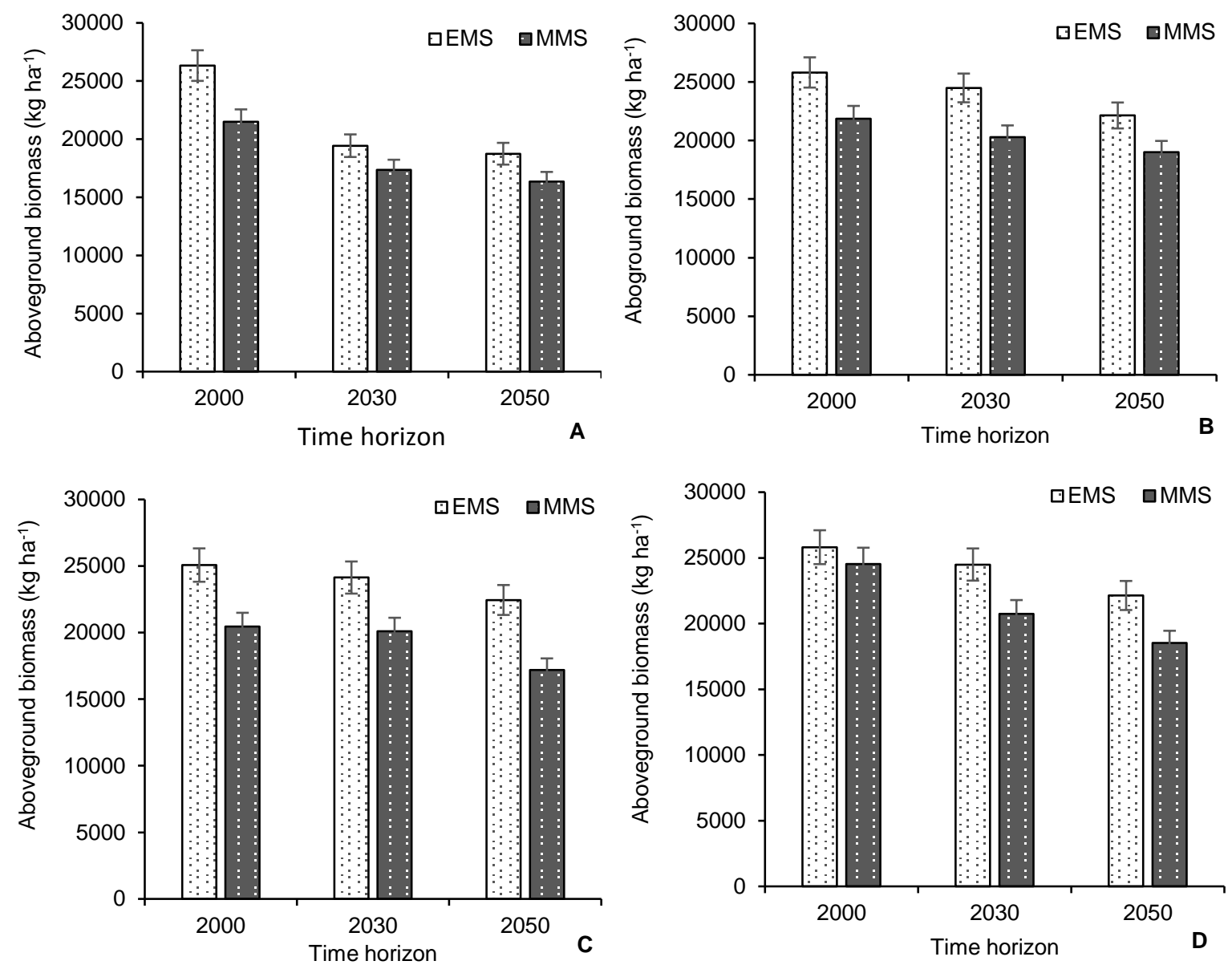

Fig. 8 Comparison of simulated rain fed aboveground biomass under different climate scenarios with $\mathrm{A}=\mathrm{ECEARTH}-\mathrm{RACMO}, \mathrm{B}=\mathrm{HadGem}-\mathrm{CCLM}, \mathrm{C}=\mathrm{MPIESM-CCLM}$ and $\mathrm{D}=$ GFDLESM-RCA using the existing (EMS) and modified (MMS) CropSyst modelling solutions for different time horizons 


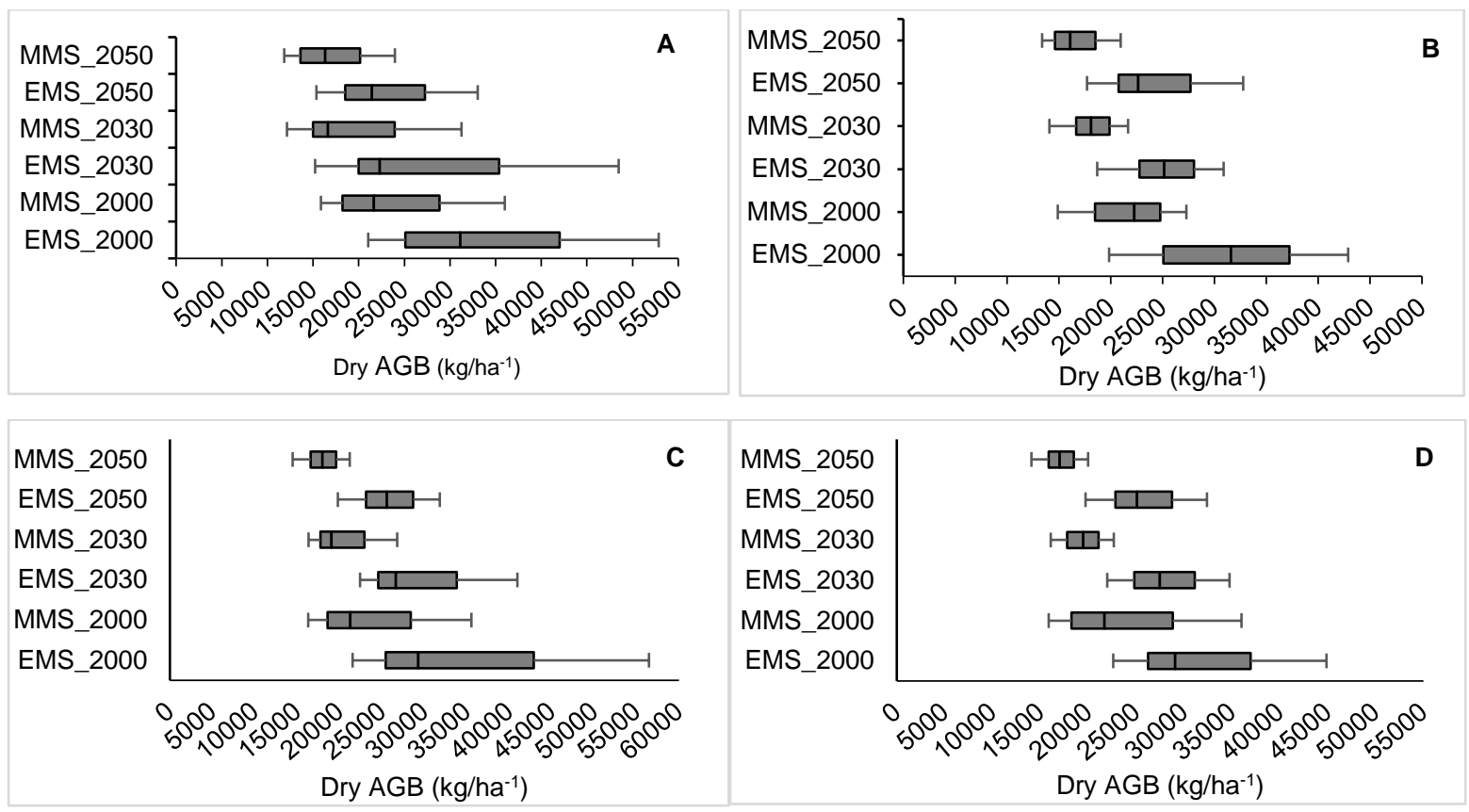

Fig. 9 Box plot showing dry aboveground biomass yield of simulated rain fed maize yields under different climate scenarios with A=ECEARTH-RACMO, B=HadGem-CCLM, $\mathrm{C}=$ MPIESM-CCLM and D=GFDLESM-RCA using the existing (EMS) and modified (MMS) CropSyst modelling solutions for different time horizons

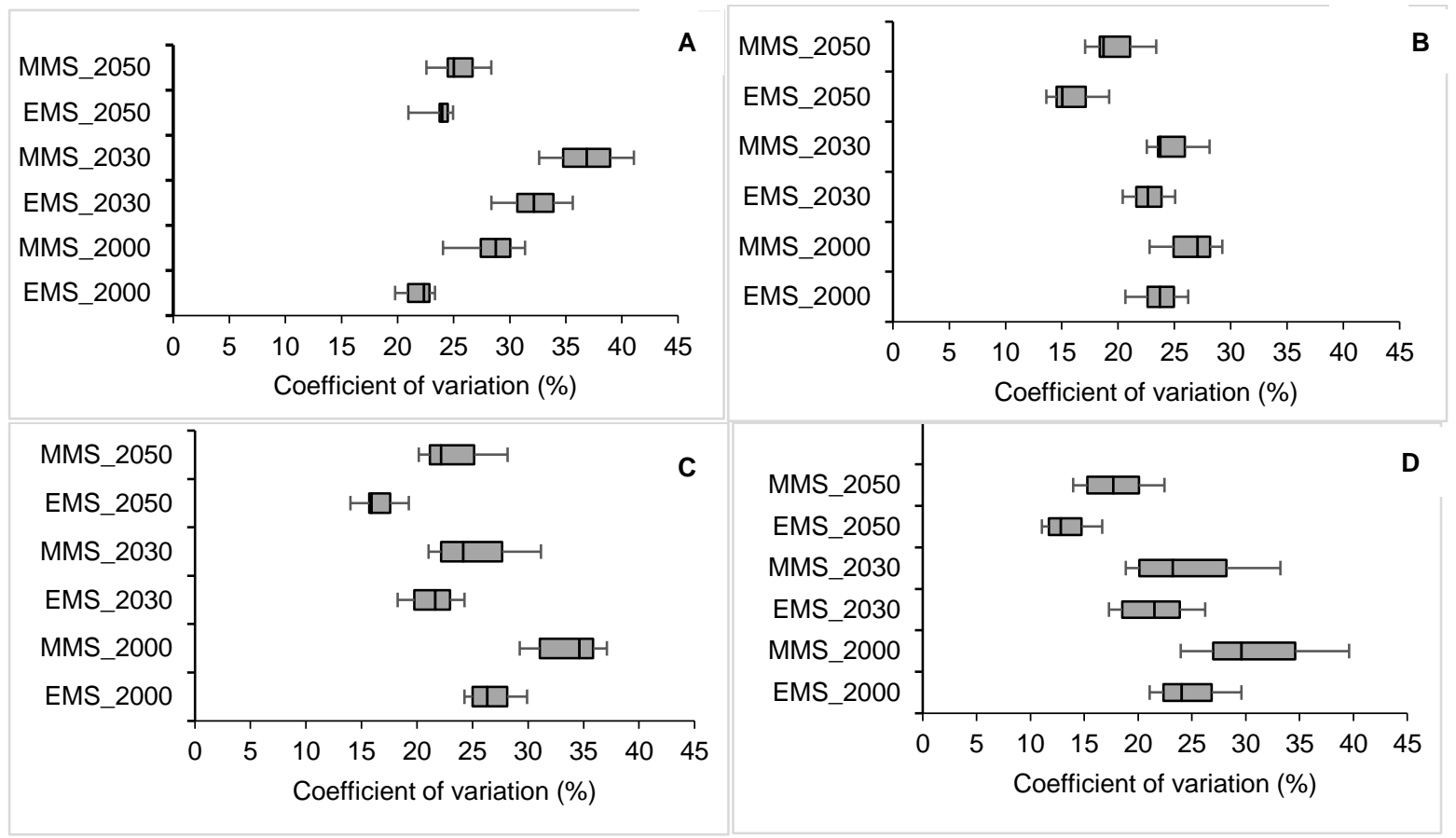

Fig. 10 Box plots comparing the coefficient of variation of simulated rain fed maize aboveground biomass under different climate scenarios with $A=E C E A R T H-R A C M O$, $\mathrm{B}=\mathrm{HadGem}-\mathrm{CCLM}, \mathrm{C}=$ MPIESM-CCLM and $\mathrm{D}=$ GFDLESM-RCA using the existing (EMS) and modified (MMS) CropSyst modelling solutions for different time horizons 


\section{Appendix}

Appendix 1 Metrics of model performance used in evaluation of the Existing and modified CropSyst models and reliability criteria (after De Jager, 1994).

\begin{tabular}{|c|c|c|c|}
\hline Performance metric & Equation & $\begin{array}{c}\text { Value range and } \\
\text { purpose }\end{array}$ & $\begin{array}{l}\text { Reliabilit } \\
\text { y Criteria }\end{array}$ \\
\hline $\begin{array}{l}\text { R, Pearson's } \\
\text { correlation } \\
\text { coefficient between } \\
\text { estimates and } \\
\text { measurements }\end{array}$ & $R=\frac{\sum_{i=1}^{n}\left(P_{i}-\bar{P}\right) \cdot\left(O_{i}-\bar{O}\right)}{\sqrt{\sum_{i=1}^{n}\left(P_{i}-\bar{P}\right)^{2} \cdot \sum_{i=1}^{n}\left(O_{i}-\bar{O}\right)^{2}}}$ & $\begin{array}{l}0 \text { to } 1: \text { the closer the } \\
\text { values are to } 1, \text { the } \\
\text { better performing the } \\
\text { model }\end{array}$ & $>0.8$ \\
\hline $\begin{array}{l}\text { EF, Modelling } \\
\text { efficiency }\end{array}$ & $E F=1-\frac{\sum_{i=1}^{n}\left(P_{i}-O_{i}\right)^{2}}{\sum_{i=1}^{n}\left(P_{i}-\bar{O}\right)^{2}}$ & $\begin{array}{l}\text { negative infinity to } 1 \\
\text { (optimum): the closer } \\
\text { the values are to } 1, \text { the } \\
\text { more efficient the } \\
\text { model with respect to } \\
\text { observed mean }\end{array}$ & - \\
\hline $\begin{array}{l}\mathrm{d} \text {, Index of } \\
\text { agreement }\end{array}$ & $d=1-\frac{\sum_{i=1}^{n}\left(P_{i}-O_{i}\right)^{2}}{\sum_{i=1}^{n}\left(\left|P_{i}-\bar{O}\right|+\left|O_{i}-\bar{O}\right|\right)}$ & $\begin{array}{c}0 \text { (absence of } \\
\text { agreement) to } 1 \\
\text { (perfect agreement): } \\
\text { the closer the values } \\
\text { are to } 1, \text { the better } \\
\text { performing the model }\end{array}$ & $>0.8$ \\
\hline $\begin{array}{l}\text { MSE, Mean square } \\
\text { error }\end{array}$ & $M S E=\frac{\sum_{i=1}^{n}\left(P_{i}-O_{i}\right)^{2}}{n}$ & $\begin{array}{c}0 \text { to positive infinity: } \\
\text { the closer the values } \\
\text { are to } 0, \text { the better the } \\
\text { model }\end{array}$ & - \\
\hline
\end{tabular}



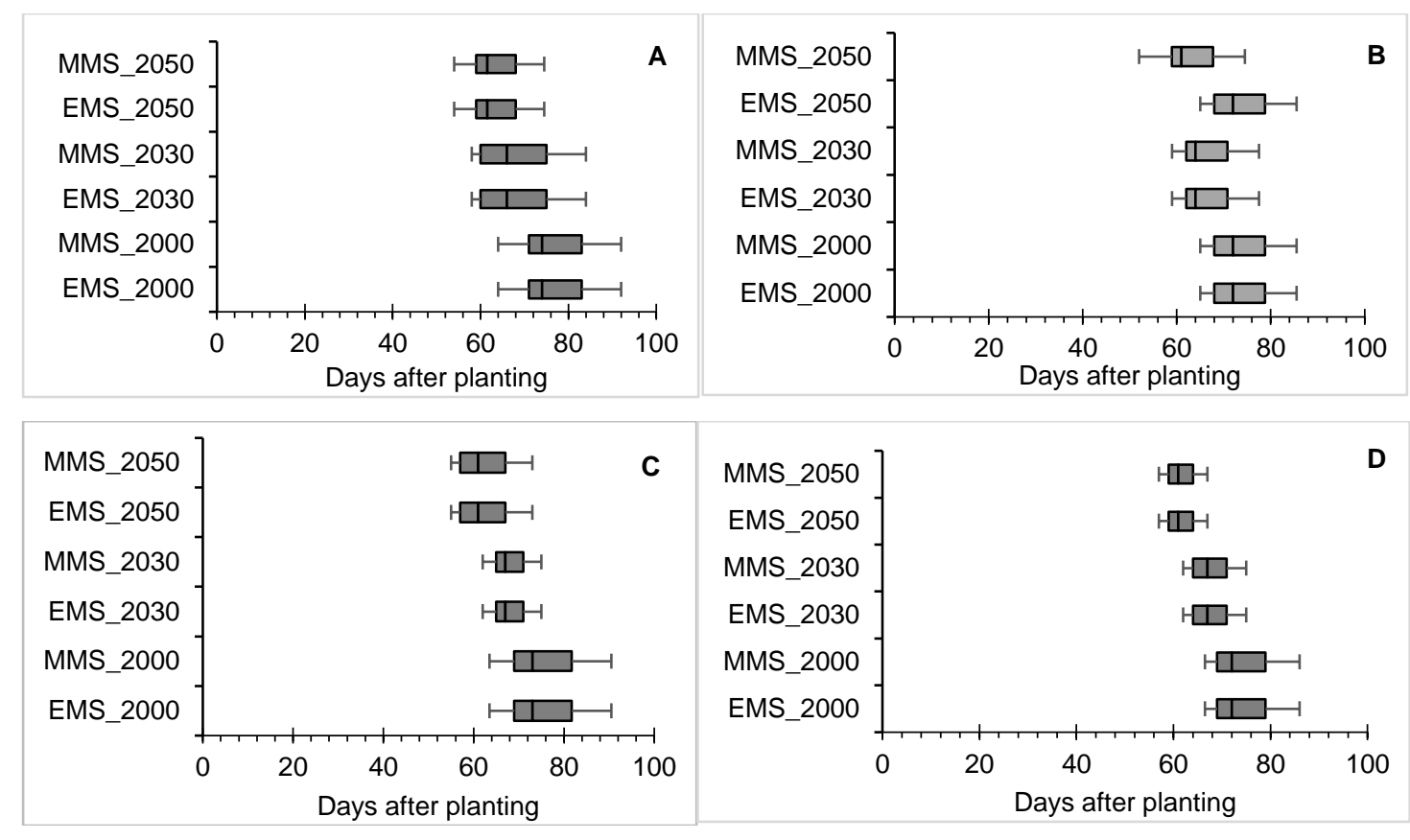

Appendix 3 Box plots comparing the flowering dates of simulated rain fed maize yields under different climate scenarios with $\mathrm{A}=\mathrm{ECEARTH}-\mathrm{RACMO}, \mathrm{B}=\mathrm{HadGem}-\mathrm{CCLM}, \mathrm{C}=\mathrm{MPIESM}-$ CCLM and D=GFDLESM-RCA using the existing (EMS) and modified (MMS) CropSyst modelling solutions for different time horizons
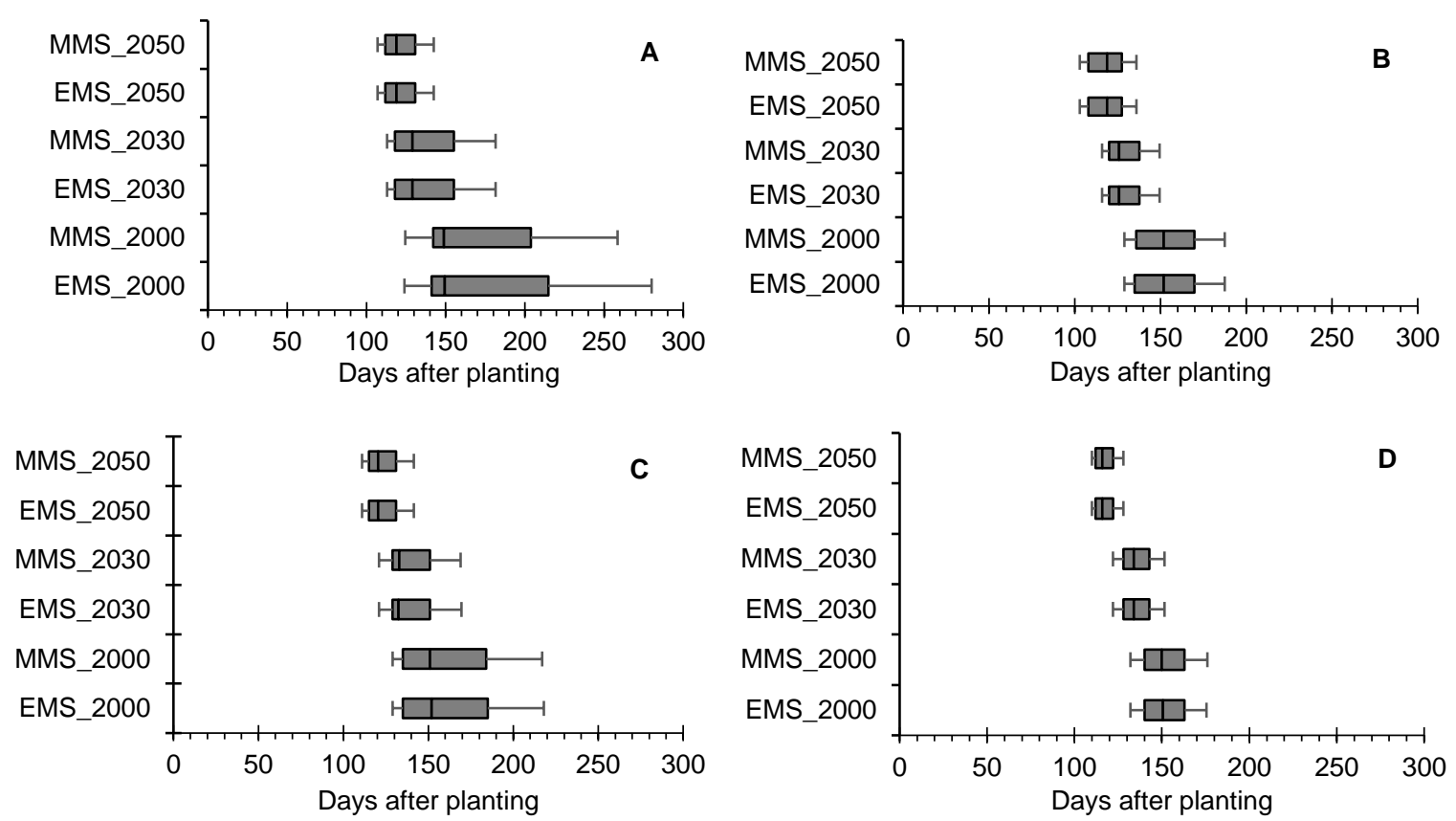

Appendix 4 Box plots comparing the maturity dates of simulated rain fed maize yields under different climate scenarios with $\mathrm{A}=\mathrm{ECEARTH}-\mathrm{RACMO}, \mathrm{B}=\mathrm{HadGem}-\mathrm{CCLM}, \mathrm{C}=\mathrm{MPIESM}-$ CCLM and D=GFDLESM-RCA using the existing (EMS) and modified (MMS) CropSyst modelling solutions for different time horizon 